2008

\title{
Terrorism's Toll on Civil Liberties
}

Nadine Strossen

New York Law School, nadine.strossen@nyls.edu

Follow this and additional works at: https://digitalcommons.nyls.edu/fac_articles_chapters

\section{Recommended Citation}

To link to this article: https://doi.org/10.1300/J146v09n03_07 To cite this article: Nadine Strossen JD (2005) Terrorism's Toll on Civil Liberties, Journal of Aggression, Maltreatment \& Trauma, 9:3-4, 365-377, DOI: 10.1300/J146v09n03_07

This Article is brought to you for free and open access by the Faculty Scholarship at DigitalCommons@NYLS. It has been accepted for inclusion in Articles \& Chapters by an authorized administrator of DigitalCommons@NYLS. 


\section{Terrorism's Toll on Civil Liberties}

\section{Nadine Strossen JD}

To cite this article: Nadine Strossen JD (2005) Terrorism's Toll on Civil Liberties, Journal of Aggression, Maltreatment \&amp; Trauma, 9:3-4, 365-377, DOI: 10.1300/J146v09n03 07

To link to this article: https://doi.org/10.1300/J146v09n03_07

曲 Published online: 22 Sep 2008.

Submit your article to this journal $2 \pi$

Џll Article views: 518

4 Citing articles: 2 View citing articles 지 


\title{
SECTION III \\ THE IMPACT OF TERRORISM \\ ON INDIVIDUALS, GROUPS \\ AND SOCIETY
}

\section{Terrorism's Toll on Civil Liberties}

\author{
Nadine Strossen
}

\begin{abstract}
SUMMARY. The toll that terrorism takes on civil liberties has become clear in the United States in the aftermath of the 9/11 attacks. Horrendous as those attacks were, they were hardly unique in the fear that they spurred on the part of the politicians and the public, resulting in a counterattack on civil liberties in the name of preventing terrorism. The cost to civil liberties is thus imposed not directly by terrorism itself, but rather by unjustified policies that are labeled "counter-terrorist." In that sense, this chapter would more aptly be entitled, "Counter-Terrorism's Toll on Civil Liberties." [Article copies available for a fee from The Haworth Document Delivery Service:
\end{abstract}

Address correspondence to: Nadine Strossen, JD, 57 Worth Street A903, New York, NY 10013 USA.

The author would like to thank, for research and administrative assistance with preparing this chapter, the following NYLS students: David Rankin, Matthew Rench, Jennifer Meyer, and Jennifer Amore.

[Haworth co-indexing entry note]: "Terrorism's Toll on Civil Liberties.” Strossen, Nadine. Co-published simultaneously in Journal of Aggression, Maltreatment \& Trauma (The Haworth Maltreatment \& Trauma Press, an imprint of The Haworth Press, Inc.) Vol. 9, No. 3/4, 2004; and: The Trauma of Terrorism: Sharing Knowledge and Shared Care, An International Handbook (ed: Yael Danieli, Danny Brom, and Joe Sills) The Haworth Maltreatment \& Trauma Press, an imprint of The Haworth Press, Inc., 2005. Single or multiple copies of this article are available for a fee from The Haworth Document Delivery Service [1-800-HAWORTH, 9:00 a.m. - 5:00 p.m. (EST). E-mail address: docdelivery@ haworthpress.com].

http://www.haworthpress.com/web/JAMT

(C) 2004 by The Haworth Press, Inc. All rights reserved.

Digital Object Identifier: 10.1300/J146v9n03_07 
1-800-HAWORTH. E-mail address: <docdelivery@haworthpress.com> Website: <http://www.HaworthPress.com> (C) 2004 by The Haworth Press, Inc. All rights reserved.]

KEYWORDS. Civil liberties, security measures, USA PATRIOT Act, minority groups

\section{THE SCAPEGOATING OF CIVIL LIBERTIES}

In the post-9/11 situation, as in the past, the many cutbacks on civil liberties have not in fact increased protection from terrorism. Ironically, too many purported "counterterrorism" measures actually advance the very goals of the terrorists themselves: they sabotage the ideals of liberty, equality and justice that the terrorists attacked, and they simultaneously divert the government from more constructive counterterrorism policies in favor of the high-profile, politically appealing tactic of scapegoating civil liberties. Real freedom is traded for the illusion of security.

This point was stressed by the celebrated FBI whistleblower, longtime agent Coleen Rowley, in a letter she wrote to FBI Director Robert Mueller in February 2003, criticizing the government's post-9/11 dragnet detention and incarceration of many Muslim immigrants from the Middle East and South Asia. "After 9-11," she wrote, "[FBI] headquarters encouraged more and more detentions for ... essentially PR [public relations] purposes. Field offices were required to report daily the number of detentions in order to supply grist for statements on our progress in fighting terrorism" (Rowley, 2003).

The foregoing typical pattern of sacrificing real rights for the semblance of safety no doubt reflects common psychological reactions to danger, as well as common political reactions. In the wake of terrorist attacks, members of the public are understandably afraid and, in a democracy, they want their government to take action to protect them. Politicians understandably want to "do something," or to be perceived as doing something, to allay their constituents' concerns.

The cheapest "quick fix" for any societal problem, including terrorist threats to national security, is to enhance government power and cut back on civil liberties. Such approaches initially require minimal resource expenditures and hence no new taxes. They tend not to engender much opposition, since there is not a large lobby for the rather abstract concept of civil liberties, especially when the issue is posed as a choice between national security and 
personal safety versus civil liberties. As polls in the 9/11 aftermath confirmed, most Americans were willing, if not eager, to trade in their freedoms in order to gain increased security or even the mere appearance of increased security.

Additionally, even more Americans were willing to trade in the freedoms of other people-for example, immigrants, or members of certain ethnic or religious minorities-in order to enhance their own security. Therefore, not surprisingly, as in all national security crises, the disproportionate targets of post-9/11 civil liberties violations are indeed members of minority groups. This phenomenon was also confirmed by Agent Rowley when she complained to FBI Director Robert Mueller that FBI field offices were subjected to "undue pressure" from FBI Headquarters after 9/11 "to detain or round up" suspects, "particularly those of Arabic origin" (Rowley, 2003).

It may well be rational to be willing to give up some freedom in return for some security, as proponents of government security measures maintain. But surely it is also rational to be unwilling to give up some freedom without gaining security in return, or if the same security gain could be achieved without giving up as much freedom. Moreover, while proponents of government security measures rightly note that life and safety are prerequisites for enjoying liberty, it is also true that liberty is a prerequisite for enjoying life and safety. Even the chief author of the PATRIOT Act, former Assistant U.S. Attorney General Viet Dinh, has cited "the boy in the bubble" as exemplifying the kind of completely safe, but completely unfree, life that would be antithetical in America. For all of these reasons, the goals of protecting civil liberties and preventing terrorism are not unalterably opposed-as too many officials and citizens assume-but rather are mutually reinforcing.

My own personal background confirms the positive interrelationship between security and freedom. My father was born in Germany in 1922 as what the Nazis called a "Jew of the second degree," since one of his parents was Jewish. For that "crime," he was imprisoned and almost died in the forced labor camp at Buchenwald. He was liberated by American armed forces and came to this country as a refugee after the war. For the rest of his life, he continued to feel, and to convey to me, his undying gratitude toward the U.S. military personnel who gave him freedom in the most literal sense.

Moreover, the U.S. forces freed him just one day before he had been scheduled to undergo forced sterilization. Therefore, I literally owe my life to the U.S. military! And I continue to depend on the U.S. military-as well as intelligence and law enforcement officials-to protect my life and our cherished American way of life. But what many of us most cherish about that way of life is precisely its dedication to the ideals of "liberty and justice for all." As the U.S. Supreme Court said, in striking down a Cold War era security measure 
that undermined constitutional rights, "It would indeed be ironic if, in the name of national defense, we would sanction the subversion of . . those liberties ... which make[s] the defense of the Nation worthwhile" (U.S. v. Robel, 1967, pp. 258, 264).

\section{THE COSTS TO THE CIVIL LIBERTIES OF EVERYONE IN THE U.S.}

Following the predictable patterns described above, it was not surprising that, promptly after the $9 / 11$ attacks, the government proposed a new law that gave it sweeping new powers of surveillance, detention, and prosecution. The law was based on the assumption that the cause of the terrorist attacks was that the government did not already have enough power to obtain information about terrorist plots. This was not supported by any evidence.

In the two years since the PATRIOT Act was passed, Congress has investigated the causes of the attacks and concluded that most of the intelligence failures had nothing to do with lack of government power to gather information, but rather resulted from the government's failure to effectively analyze and act on the massive amounts of information it already possessed through its already great surveillance powers. Moreover, many of the government's intrusive new surveillance powers can be exercised not only against suspected terrorists but also against law-abiding citizens who are not suspected of any crime at all. Therefore, these measures are the worst of both worlds: they do demonstrably violate the freedoms of everyone in the U.S., but they do not demonstrably enhance national security.

Under one section of the PATRIOT Act, government agents may obtain any records about anyone from any entity that holds them, so long as the government "specif[ies]" that the records are sought in connection with a terrorism investigation (USA PATRIOT Act, 2001, Section 215). On that basis, even our most personal records can be turned over by banks, hospitals, Internet Service Providers, libraries, universities, and any other of the multiple entities that maintain personal information about us. This enormous new power not only violates fundamental privacy rights, but it also endangers freedom of speech, since many of us may well be deterred from such activities as borrowing certain library books, or visiting certain Websites, knowing that the government can be looking over our shoulders as we read.

The same chilling effect on free speech and other First Amendment rights follows from another expansive post-9/11 surveillance power: the Attorney General's guidelines, issued in May 2002, which allow government agents to infiltrate secretly any gatherings, including political meetings and religious worship services, even without any suspicion whatsoever that any participants 
are engaging in illegal activities. This was precisely the kind of political spying that targeted Martin Luther King and many other pro-civil rights and anti-Vietnam War activists a generation ago, prompting Congressional hearings and investigative guidelines that prohibited surveillance without at least some suspicion of criminal activity. In the 9/11 aftermath, Attorney General John Ashcroft unilaterally rolled back those protections and again unleashed government power to spy on Americans merely because of their political and religious beliefs.

While the government's increased surveillance powers can be used against anyone, including American citizens, since 9/11 many publicized government investigative programs have singled out Muslim immigrants from the Middle East and South Asia. Therefore, individuals in these groups reasonably fear that they are the prime targets of clandestine surveillance measures. Immigrants and Muslims have said that they are no longer attending meetings or religious services for fear that they will be subject to government surveillance and harassment. Even if they "have nothing to hide" in terms of any wrongdoing, they understandably still do not want government officials to spy surreptitiously on their political and religious expressions and beliefs.

It is becoming increasingly difficult to maintain some sphere of personal privacy that the government may not invade even with no specific justification. "Thanks" to rapidly developing information-gathering technology, including the linking of computerized databases, we are approaching the dystopia depicted in George Orwell's classic novel 1984. One's freedom of action certainly can be limited by the fear of facing a terrorist attack, but it may also be limited by the fear, or indeed, knowledge, that "Big Brother is watching."

\section{THE DISPROPORTIONATELY HIGH COSTS TO THE CIVIL LIBERTIES OF CERTAIN MINORITY GROUPS}

While precious rights of everyone in the U.S. have been forfeited in the domestic "War on Terrorism," the rights of some people have been hit especially hard, namely, young Muslim men from certain countries in the Middle East (including Israel) and South Asia. Thousands have been interrogated and hundreds have been incarcerated, in secret, based only on national origin and religion. In a scathing report issued in June 2003, the Justice Department's own Inspector General concluded that these "indiscriminate and haphazard" arrests and detentions led to the prolonged incarceration of hundreds of individuals who had no ties whatsoever to terrorism (Department of Justice, 2003). Worse 
yet, many were held incommunicado without access to lawyers or family members and in inhumane conditions.

These current discriminatory practices replicate the errors of the past, when the U.S. government repeatedly has demonized particular immigrant groups as alleged national security threats based on no individualized suspicion but rather on ethnic prejudices. While the post-9/11 incarcerations involved "only" hundreds of innocent immigrants-as opposed to the 120,000 innocent Japanese-Americans who were incarcerated during World War II-the very same principles are at stake. The well-respected legal journalist Stuart Taylor wrote: "Despite the unprecedented secrecy imposed by Attorney General John Ashcroft, evidence has mounted that [since September 11, 2001] his Justice Department has put hundreds of harmless Muslim men from abroad behind bars for far too long, treated many of them worse than convicted criminals, and arguably violated their constitutional rights-all without finding enough evidence to charge a single one ... with a terrorist crime" (Taylor, 2002, p. 52).

Disproportionate sacrifices of the rights of "the usual suspects," members of targeted minority groups, create a false sense on the part of the majority of our citizenry that only "other people's rights are at stake." The lesson the American Civil Liberties Union has been trying to teach in the current climate is that it is not only wrong to demonize Muslim men from certain countries, but also that everyone else has a direct personal stake in righting this wrong. This fundamental concept was memorably captured by Stephen Rohde, a civil liberties lawyer in Los Angeles, who composed a post-9/11 variation on the famous 1937 prose poem by the Reverend Martin Niemoller about Nazi Germany. Stephen Rohde's (2001) moving words follow:

First they came for the Muslims, and I didn't speak up because I wasn't a Muslim.

Then they came for the immigrants, detaining them indefinitely solely upon the certification of the Attorney General, and I didn't speak up because I wasn't an immigrant.

Then they came to eavesdrop on suspects consulting with their attorneys, and I didn't speak up because I wasn't a suspect.

Then they came to prosecute non-citizens before secret military commissions, and I didn't speak up because I wasn't a non-citizen.

Then they came to enter homes and offices for unannounced "sneak and peek" searches, and I didn't speak up because I had nothing to hide. 
Then they came to reinstate Cointelpro and resume the infiltration and surveillance of domestic religious and political groups, and I didn't speak up because I no longer participated in any groups.

Then they came to arrest American citizens and hold them indefinitely without any charges and without access to lawyers, and I didn't speak up because I would never be arrested.

Then they came to institute TIPS, the Terrorism Information and Prevention System, recruiting citizens to spy on other citizens, and I didn't speak up because I was afraid.

Then they came to institute Total Information Awareness, collecting private data on every man, woman and child in America, and I didn't speak up because I couldn't do anything about it.

Then they came for immigrants and students from selective countries luring them under the requirement of "special registration" as a ruse to seize them and detain them, and I didn't speak up because I was not required to register.

Then they came for anyone who objected to government policy because it only aided the terrorists and gave ammunition to America's enemies and I didn't speak up . . . because I didn't speak up.

Then they came for me and by that time no one was left to speak up.

\section{THE THREAT TO FREE EXCHANGE OF INFORMATION}

As the Rohde/Niemoller piece underscores, a critical right, especially in the counter-terrorism context, is the right "to speak up" against government abuses. Great costs to civil liberties, in the current security crisis as well as others, result from the government's efforts to stifle dissent. This specific type of rights violation is particularly pernicious since it hampers efforts to counter all other rights violations. Since 9/11, the U.S. government has sought to suppress criticism in many ways, both indirectly, by suggesting that dissent is unpatriotic, and directly, by illegally arresting individuals who are simply seeking to exercise their right to peaceful protest. These crackdowns on fundamental First Amendment freedoms violate not only the core individual right of self-expression, but also an essential tenet of democratic self-government: that "We the People" must be free to criticize the policies that our elected representatives adopt in our name. 
An early effort to discourage criticism of the government's anti-terrorism policies occurred only weeks after the terrorist attacks, with the government's heavy-handed promotion of its draconian new, so-called "anti-terrorism" law. I use the term "so-called" to underscore that most of the law's intrusive new powers apply to people who are suspected of non-terrorist crimes, and some even apply to people who are suspected of no wrongdoing at all. The law's title, the "USA PATRIOT" Act, signifies that anyone who dares to dissent from this law, or to criticize it, is not patriotic, or at least will face politically powerful charges of lack of patriotism.

The message that true patriots willingly give up freedom and hand over power to the government during national security crises was asserted even more explicitly by U.S. Attorney General John Ashcroft in testimony before the U.S. Senate Judiciary Committee in December, 2001. He charged that anyone who raised what he derided as "phantoms of lost liberty" would "only aid terrorists" and "give ammunition to America's enemies."1 This charge was especially harsh, since it closely echoed the U.S. Constitution's definition of treason. $^{2}$

Following historic patterns, since $9 / 11$ both federal and local officials have employed a variety of tactics not only to discourage individuals from expressing critical opinions but also to make it difficult for government leaders and the general public to hear those opinions even when they are expressed. For example, in cities throughout the U.S., peaceful demonstrators against the war in Iraq have been subjected to various forms of official mistreatment, from physical abuse, to false arrest, to interrogations about their political and religious beliefs. Moreover, when President Bush or other top Administration officials make public appearances, the Secret Service has consistently restricted members of the public who seek to criticize Administration policies to locations that are far away not only from the officials at whom the messages are aimed, but also from the TV cameras that are covering the officials' appearances (American Civil Liberties Union, 2003). This policy not only violates the cherished First Amendment rights of the would-be protestors themselves, but it also violates the First Amendment rights of everyone in this country, since we are deprived of information about the range and strength of perspectives on these critically important issues that so profoundly affect us all.

In addition to preventing or discouraging citizens from conveying critical viewpoints to their elected officials post-9/11, the government also has completely silenced many communications that should be taking place in the other direction-from the government to the citizenry. The government has thrown an unprecedented shroud of secrecy over essential aspects of its counter-terrorism policies in ways that are not justified by security concerns. This makes it impossible for "We the People" to assess what our government is doing in 
our name. For example, the Bush Administration has consistently refused to provide even statistical information about how it is deploying the intrusive new surveillance powers it gained under the Patriot Act. The government has pursued blanket policies of secret arrests, secret incarcerations, secret deportation hearings, and secret deportations without justifying the need for such secrecy in any particular instance. In lawsuits brought by the ACLU and our allies to challenge these sweeping secrecy policies, judges have denounced the policies as "odious to a democracy" (American Civil Liberties Union v. County of Hudson, 2002). In one widely quoted pronouncement, federal appellate Judge Damon Keith decried the secret deportation policy by declaring, "Democracies die behind closed doors" (Detroit Free Press v. Ashcroft, 2002, p. 683).

\section{THE COSTS TO THE CONSTITUTIONAL SYSTEM OF CHECKS AND BALANCES}

In addition to undermining democratic self-government through suppressing the free flow of information and ideas between government officials and citizens, the current counter-terrorism policies have also eroded another essential pillar of our democracy: the system of checks and balances designed to prevent any single branch of government from amassing excessive power and abusing individual rights. A pervasive pattern running through many post-9/11 policies, as well as many prior anti-terrorism policies, is the consolidation of power in the executive branch of government, thus substantially diminishing the powers of both other branches of the federal government, the Congress and the courts.

The Administration has circumscribed Congress's powers in several ways. First, it has exerted enormous pressure on members of Congress to rush through laws that it asserts to be essential to the anti-terrorist arsenal, such as the PATRIOT Act, with only minimal deliberations, in derogation of standard legislative processes. The executive branch prevailed upon Congress to pass this lengthy, complex Act in record time, even before most members of Congress had had time to read it. Second, the executive branch has thwarted Congress's attempts to exercise its important oversight responsibilities to ensure that government officials are exercising their pervasive new powers in ways that do not abuse individual rights. Administration officials have stonewalled Congress's requests for information and documents, provoking harsh criticism even from some Republican members of Congress. Third, the executive branch has unilaterally implemented many rights-restricting anti-terrorism policies on its own without even consulting with Congress, let alone seeking Congressional authorization. 
The Administration has resisted Congress' effective participation in counter-terrorism policymaking with a "trust us" argument: trust us to know what is best for the American people. Politicians and members of the public might well find such an argument appealing in one significant sense because of an understandable desire to be able to trust our national leaders at times of crisis. Whatever the psychological realities that encourage many individuals to accept the government's self-described beneficence on the basis of trust or faith, political and historical realities demonstrate that the "trust us" approach is a thin reed on which to rest either liberty or democracy. The great former U.S. Supreme Court Justice Louis Brandeis eloquently explained this, in a much-quoted opinion: "Experience should teach us to be most on our guard to protect liberty when the government's purposes are beneficent. ... The greatest dangers to liberty lurk in insidious encroachment by men of zeal, well-meaning but without understanding" (Olmstead v. United States, 1928, pp. 438, 479). Justice Brandeis's insight is in fact hard-wired into the U.S. constitutional system of checks and balances.

Even more dangerous to civil liberties and democracy than the Administration's attempts to reduce, and in some instances, even to eliminate Congress's role in shaping anti-terrorism policies is the Administration's consistent erosion of the checking powers of the third branch of our federal government, the federal courts. The framers of the U.S. Constitution deliberately provided some distance between the federal courts and the electorate in order to maximize judicial independence. Since federal judges are appointed rather than elected, and since they have lifetime tenure, they are well positioned to serve as the ultimate safety net for the rights of individuals and members of minority groups when elected officials are not as likely to protect these rights. This role of the federal courts is especially important in times of national security crisis, when elected officials are particularly susceptible to political pressures-as illustrated, for example, by the very few votes against the Patriot Act, despite its many cutbacks on fundamental freedoms and despite the lack of any showing that these new powers would even be effective in countering terrorism, let alone necessary to do so.

To counter this tendency of politicians to succumb to political and popular pressures, especially during times of crisis, it is in those very times that the courts must most rigorously review government actions to ensure that they do not unjustifiably sacrifice the rights of individuals or minority groups. This point was stressed by the Chief Justice in Israel, a country that certainly has had more than its share of terrorist attacks. Aharon Barak, President of the Israeli Supreme Court, said: "The real test of [judicial] independence and impartiality comes in situations of war and terrorism.... Precisely in these times, we judges must hold fast to fundamental principles and values; we must embrace 
our supreme responsibility to protect democracy and the constitution" (Lewis, 2003, p. A-17).

In short, vigorous judicial review is more important than ever in the context of counter-terrorism efforts. Unfortunately, since 9/11 too many anti-terrorism policies have moved in exactly the opposite direction to cut back or even eliminate the courts' time-honored power to check executive branch overreaching and to protect individual rights. Judges no longer may exercise meaningful review over secret seizures of personal records from any entity that holds them, secret searches and seizures of items in homes and offices, interception of communications between attorneys and their clients, and the holding of certain hearings in secret.

The most dramatic Administration post-9/11 assertion of unilateral power, with the exclusion of meaningful judicial review, concerns "enemy combatants." I put that term in quotes, since it is not a legal term of art and the Administration has not defined it, other than to describe one American citizen whom it labeled an "enemy combatant" as being "a bad guy" ("Dirty Bombs," 2002). The President has claimed the power to pronounce anyone, including an American citizen who is arrested in the U.S., to be an "enemy combatant." Moreover, once the Administration has tarred someone with that stigmatizing label, it also asserts the power to imprison him or her indefinitely, incommunicado, without charge, without trial, and without access to a lawyer or anyone else. The Administration has further claimed that the courts are powerless to review the "enemy combatant" designation and its draconian consequences so long as it produces "some evidence," no matter how conclusory or questionable, in support. Such unfettered, unchecked government power is antithetical to both personal liberty and democratic government. That conclusion is confirmed by a sadly apt comment that Winston Churchill made in 1943:

The power of the executive to cast a man into prison without formulating any Charge ... and to deny him the judgment of his peers, is in the highest degree odious, and the foundation of all totalitarian governments, whether Nazi or Communist. (The United Kingdom Parliament Joint Committee on Human Rights, 2003, February)

\section{CONCLUSION}

The costs to civil liberties resulting from U.S. post-9/11 counter-terrorism efforts reflect consistent patterns that we see whenever any government seeks to protect national security against serious threats. As we have learned from 
past experience, too many sacrifices of civil liberties prove in retrospect to be not only unprincipled, but also unpractical. This is especially true when the victims are members of minority groups who are targeted because of who they are, not what they have done. By demonizing innocent people, we deflect attention from guilty ones. As President George W. Bush declared, in his first words to a shattered nation on that dreadful date of September 11, 2001, the terrorists attacked the U.S. because it is "the brightest beacon for freedom and opportunity in the world," and he vowed that "No one will keep that light from shining" (Bush, 2001). Accordingly, if our own counter-terrorism policies dim the very light of liberty that the terrorists targeted, that would be the greatest cost of all, not only to civil liberties, but also to our struggle against terrorism.

\section{NOTES}

1. This is a close paraphrase of Attorney General John Ashcroft's testimony before the Senate Judiciary Committee on December 6, 2001, in which he said that the government's civil libertarian critics would "only aid terrorists" and "give ammunition to America's enemies."

2. U.S. Constitution, Article III, Section 3: "Treason against the United States, shall consist ... in adhering to their Enemies, giving them Aid and Comfort."

\section{REFERENCES}

American Civil Liberties Union. (2003). Freedom under fire: Dissent in post 9/11 America. New York: Author.

American Civil Liberties Union v. County of Hudson. (2002, March 27). No. HUD-L-463-02. Hudson City: New Jersey Superior Court.

Ashcroft, J. (2001, December 6). DOJ oversight: Preserving freedoms while defending against terrorism. Hearing before the Senate Committee on the Judiciary, 107th Congress.

Bush, G.W. (2001, September). Statement in his Address to the nation. Washington, DC. Copy of the transcript available at www.whitehouse.gov

Department of Justice. (2003, June). Report on the September 11 detainees: A review of the treatment of aliens held on immigration charges in connection with the investigation of the September 11 attacks. Washington, DC: Government Publishing Office.

Detroit Free Press v. Ashcroft, 303 F.3d 681, 683 (6th Cir. 2002).

Dirty bombs and civil rights. (2002, June 12). The New York Times, p. A-28.

Lewis, A. (2003, February 24). Marbury v. Madison v. Ashcroft. The New York Times, p. A-17.

Olmstead v. United States, 277 U.S. 438, 479 (dissenting opinion) (1928).

Rohde, S. (2001). Then they came for me. (Inspired by the Rev. Martin Neimoller, 1937). Unpublished manuscript. 
Rowley, C. (2003, February 26). Rowley Letter to FBI Director. Published March 6, 2003. Retrieved from: http://www.startribune.com/stories/484/3738192.html

Taylor, S. Jr. (2002, June 3). Stop locking up Muslims. Legal Times, p. 52.

The United Kingdom Parliament Joint Committee on Human Rights. (2003, February). Continuance in force of Sections 21 to 23 of the Anti-Terrorism, Crime and Security Act 2001. Fifth report.

U.S. v. Robel, 389 U.S., 258-264 (1967).

USA PATRIOT Act. Business Records Provision. 50 USC $§ 1861$ (2003)(b)(2). 